\title{
The Effectiveness Of Methaporical Thinking Approach To Improve The Mathematical Representation Ability
}

\author{
Irajuana Haidar $^{1)}$, Jahring ${ }^{2)}$ \\ ${ }^{1,2}$ Universitas Sembilanbelas November Kolaka

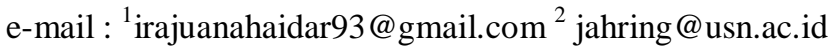

\begin{abstract}
This research is an experimental research which aims to describe the effectiveness of the methaporical thinking approach to improve the mathematical representation ability of class VIII SMPN 2 Toari. In addition, it also aims to determine how much students are engaged in the learning process when applying the methaporical thinking approach. The research subjects were divided into two groups, namely the experimental group taught using the methaporical thinking approach and the control group taught by conventional learning. The results showed that students who were taught with a methaporiical thinking approach were more active in the learning process so that the ability of representation also increased. In addition, it was found that mean of mathematical representation ability of students taught using the approach of methaporical thinking was better than students taught with conventional learning. Therefore, the approach of methaporical thinking is able to improve the mathematical representation ability of class VIII SMPN 2 Toari.
\end{abstract}

Keyword: methaporical thinking, mathematical representation

\section{INTRODUCTION}

The development of science and technology (science and technology) in this globalization era is very rapid and has an impact on all lines of life. The existence of these developments must be supported by competent human resources which of course can only be obtained through good education. The competency needed is the ability to obtain, manage and utilize the Science and Technology proportionately. This ability requires systematic, logical, and critical thinking which can be developed through mathematics learning (Sundayana, 2014). According to Muzaini (Firdaus, 2019) Mathematics is one of the subjects in each type and level of education, both general education and vocational education, from basic education to tertiary education. Mathematics is identical to the presence of symbols, charts, graphs, pictures, words, and tables. But not everyone is able to understand the symbols or graphics in mathematics. Therefore, mathematical representation ability is needed. According to Jones \& Knuth (Sabirin, 2014) that mathematical representation is a model or substitute form of a problem situation that is used to find solutions. For example, a problem can be represented by objects, images, words or mathematical symbols.

The ability of mathematical representation is one of the mathematical abilities that must be possessed by every student because representation is the center of mathematics learning. Students can develop and deepen their understanding of concepts and relationships between mathematical concepts they already have by making, comparing and using representations, (NCTM, 2000). Between understanding mathematics, mathematical communication and mathematical representation have a very close relationship. Because to communicate understanding of mathematics, one must have good representation 
skills. Mudzakkir (Suryana, 2012) the ability of students' mathematical representations can be seen from several representational activities carried out, including: (1) Visual representations, including diagrams, graphs or tables, and pictures; (2) mathematical equations or expressions; and (3) written words or text.

Based on observations made in class VIII of SMP Negeri 2 Toari, Kolaka Regency, shows that the mathematical representation ability is low. This is one of them marked by the difficulty of students when faced with story problems on straight line equation material. Students find it difficult to represent mathematical ideas such as drawing pictures, tables or mathematical models from the information presented in the problem. The main factors causing it are the learning approaches used by teachers that are not varied, less attractive, and teacher unpreparedness in teaching, as well as the lack of interaction between one student and other students in discussing existing problems. Therefore it is necessary to apply a learning that can make students able to represent problems or materials, both in the form of visuals, mathematical expressions, as well as words or written text.

Many alternatives can be applied so that learning is more interesting. One way is to use metaphors. Metaphors have an important role in learning to increase student interest and motivation, because the presentation of metaphors will bring students in an atmosphere full of excitement and novelty, (De Porter, 2000). So according to Howard and Gardner (De Porter, 2000) students will learn with all their abilities if students like what students learn and will feel happy to be involved in it. With metaphors students can better understand and interpret mathematics not just memorizing formulas. The metaphor given can be in the form of a parable or stimulation so that students' confidence will be increased and easy to understand the mathematical concepts given. Hendriana (Saputri, 2012) argues that methaporical thinking is a bridge between models and interpretations, provides great opportunities for students to exploit their knowledge in learning mathematics, and through methaporical thinking students' learning processes become meaningful because students can see the relationship between the concepts learned and the concepts he already knew.

In the methaporical thinking approach, the teacher provides contextual problems in the form of metaphors of a concept, then students identify the concepts contained in the problem and make other metaphors from the concept. In identifying concepts, students need to connect the mathematical ideas they have. To do this, students can represent it through pictures, tables, graphs, mathematical expressions, and written text. Activities in the methaporical thinking learning approach provide opportunities for students to express their mathematical ideas openly. The ability of students to present mathematical ideas that they build themselves and the results of discussions in groups is what is meant by the ability of mathematical representation.

Therefore, this study aims to find out whether the methaporical thinking approach is able to improve the representation ability of the eighth grade students of SMPN 2 Toari Kolaka Regency, also to find out the percentage of students' 
activeness in participating in learning if the teacher has carried out learning according to the procedures that were planned before.

\section{RESEARCH METHODS}

This type of research is experimental research, that is research used to look for certain influences on others under controlled conditions, (Sugiyono, 2015). This research is included in the quasi-experimental form, namely the design of experimental research conducted under conditions that do not allow controlling or manipulating all relevant variables, (Danim, 2003). This study uses two classes, namely, the experimental class and the control class. Learning with the methaporical thinking approach is applied to the experimental class and conventional learning is applied to the control class. The population of this research was all students of class VIII of SMPN 2 Toari in the odd semester of the 2018/2019 school year. The sample consisted of two classes totaling 53 people. The sample was selected by cluster random sampling, which is a simple group sampling method, namely by group randomization, Dantes (2012). In order to obtain class VIIIB as an experimental class applying learning with a methaporical thinking approach, and class VIIIA as a control class applying conventional learning.

The research instrument used was a test of students' mathematical representation abilities, an observation sheet of teacher and student activities during the learning process. Tests are given before and after treatment (non equivalent control group design). Student activity observation sheets are given during the learning process to observe student activities during the learning process using the methaporical thinking approach. The data obtained were analyzed using descriptive and inferential statistical analysis. Data on the mathematical representation test results were analyzed to obtain a gain normalization score (N-Gain) in both classes. This was done to find out the improvement of students' mathematical representation ability in the experimental class and the control class using the Hake formula (Meltzer, 2002), with the following criteria:

Table 1. Category of Obtaining N-Gain Score

\begin{tabular}{cc}
\hline Limitation & Category \\
\hline $\mathrm{g}>0,7$ & High \\
$0,3<\mathrm{g} \leq 0,7$ & Medium \\
$\mathrm{g} \leq 0,3$ & Low \\
\hline
\end{tabular}

Inferential sample data are analyzed to draw a conclusion to the population. Inferential statistical analysis was performed to test the research hypothesis. But before that the prerequisite test was done which included a normality test and a homogeneity test. 


\section{RESULTS AND DISCUSSION \\ Analysis of Mathematical Representation Ability}

The results of descriptive analysis of the score of mathematical representation ability in class VIIIB students before being treated (pretest) and after being given a treatment (posttest) applying the methaporical thinking approach and class VIIIA applying conventional learning.

Table 2. Description of the Mathematics Representation Ability Score of the Second Student Learning Group

\begin{tabular}{ccccc}
\hline \multirow{2}{*}{ Statistik } & \multicolumn{4}{c}{ Statistik Value } \\
\cline { 2 - 5 } & Methaporical Thinking & \multicolumn{2}{c}{ Konvensional } \\
\cline { 2 - 5 } & Pretest & Posttest & Pretest & Posttest \\
\hline Ukuran Sampel & 29 & 29 & 24 & 24 \\
Skor Ideal & 100 & 100 & 100 & 100 \\
Skor Maksimum & 59,62 & 88,46 & 51,92 & 82,69 \\
Skor Minimum & 34,62 & 69,23 & 32,69 & 61,54 \\
Rata-rata & 46,42 & 77,45 & 43,03 & 71,15 \\
Standar Deviasi & 5,384 & 5,744 & 5,344 & 6,589 \\
Variansi & 28,985 & 32,993 & 28,561 & 43,414 \\
\hline
\end{tabular}

In table 2. shows that the average score of mathematical representation ability of experimental class students in the material of straight-line equations before being given a treatment (pretest) is 46.42 of the ideal score of 100 , while the average score of the ability of mathematical representation of students on straight-line equation material after being given a treatment (posttest) was 77.45 out of an ideal score of 100. This shows that in class VIIIB of SMP Negeri 2 Toari, Kolaka Regency that applied the methaporical thinking approach there was an increase of 31.03 .

In table 2. it also shows that the average score of the ability of mathematical representation of control class students on the material of straightline equations before being given a treatment (pretest) is 43.03 of the ideal score of 100 , while the average score of the ability of mathematical representation of students on the material of line equations straight after being given a treatment (posttest) was 71.15 out of an ideal score of 100. This shows that in class VIIIA SMP Negeri 2 Toari Kolaka Regency that applied conventional learning an increase of 28.12 .

The results of descriptive analysis of mathematics representation ability scores in VIIIB grade students before being treated (pretest) and after being given treatment (posttest) applying methaporical thinking approach and class VIIIA 
applying conventional learning in terms of each aspect / indicator of students' mathematical representation ability.

Table 3. Average Recapitulation of Each Aspect of the Mathematical Representation Ability of Second Class Students

\begin{tabular}{clcccc}
\hline \multirow{2}{*}{ No } & \multirow{2}{*}{ Measured Aspects } & \multicolumn{2}{c}{ Eksperimen Class } & \multicolumn{2}{c}{ Control Class } \\
\cline { 3 - 6 } & & Pretest & Posttest & Pretest & Posttest \\
\hline 1 & Visual Representation & 50 & 79,53 & 34,91 & 60,34 \\
2 & Representation of & 46,21 & 75,69 & 38,10 & 61,55 \\
& Mathematical Expressions & 44,40 & 78,02 & 34,48 & 54,31 \\
3 & Representation of words & & & & \\
\end{tabular}

In table 3. shows that the average score of aspects of the visual representation of the experimental class on the material of the straight-line equation before being given a treatment (pretest) is 50 , while the average score of the aspect of the visual representation of the experimental class on the material of the straight-line equation after being given a treatment (posttest) is 79.53. This shows that in class VIIIB of SMP Negeri 2 Toari, Kolaka Regency which applied the methaporical thinking approach there was an increase in visual representation by 29.53. The average score of aspects of the representation of mathematical expressions before being given a pretest is 46.21 , while the average score of the aspects of the representation of mathematical expressions after being given a treatment (posttest) is 75.69. This shows that in class VIIIB of SMP Negeri 2 Toari, Kolaka Regency which applied the methaporical thinking approach there was an increase in the aspect of mathematical expression representation by 29.48 . The average score of aspects of the representation of words before being treated (pretest) was 44.40, while the average score of aspects of representation of words after being treated (posttest) was 78.02. This shows that in class VIIIB SMP Negeri 2 Toari, Kolaka Regency which applied the methaporical thinking approach there was an increase in the aspect of words representation by 33.62 .

In table 3. also shows that the average score of aspects of the visual representation of the control class on the material of the straight-line equation before being given a treatment (pretest) is 34.91, while the average score of the aspect of the visual representation of the experimental class on the material of the straight-line equation after being treated (posttest) is 60.34. This shows that in class VIIIB of SMP Negeri 2 Toari, Kolaka Regency which applied the methaporical thinking approach there was an increase in visual representation by 25.43. The average score of aspects of representation of mathematical expressions before being given a pretest is 38.10, while the average score of aspects of representation of mathematical expressions after being given a treatment (posttest) is 61.55. This shows that in class VIIIB of SMP Negeri 2 Toari, Kolaka Regency which applied the methaporical thinking approach there was an increase in the aspect of mathematical expression representation by 23.45. The average score of aspects of the representation of words before being treated (pretest) was 34.48, while the average score of aspects of representation of words after being treated 
(posttest) was 54.31. This shows that in class VIIIB SMP Negeri 2 Toari Kolaka Regency which applies the methaporical thinking approach there is an increase in the aspect of the representation of words amounting to 19.83

To see the percentage increase (N-Gain) students' mathematical representation ability in both classes can be seen in the following table.

Table 4. Improved Test Results (N-Gain) Ability of Mathematical Representation Class Eksperimen Class Control Class

\begin{tabular}{ccc}
\hline $\mathrm{S}_{\text {pretest }}$ & 46,42 & 43,03 \\
$\mathrm{~S}_{\text {posttest }}$ & 77,45 & 71,15 \\
$N$-Gain & 0,57 & 0,49 \\
\hline Category & Medium & Medium
\end{tabular}

Based on Table 4. the results of the calculation of the gain in the experimental class (Class VIIIB) obtained an average pretest of 46.42 and an average posttest of 77.45 so that a gain value of 0.57 is obtained. This interprets that the experimental class has increased the ability of mathematical representation in the medium category. In the control class (Class VIIIA) obtained an average pretest of 43.03 and an average posttest of 71.15 to obtain a gain value of 0.47. It is interpreted that the control class has increased the ability of mathematical representation in the medium category. Both classes have increased mathematical representation and both are in the moderate category, but can be seen from the average posttest score of the experimental class reaching the minimum completeness criteria (KKM) so that it can be concluded that the class VIIIB SMP Negeri 2 Toari Kolaka Regency on the material of straight line equations with the approach of learning methaporical thinking can affect the ability of students' mathematical representation.

The results of inferential analysis showed that the average score of students' mathematical representation ability after learning mathematics with the methaporical thinking approach obtained p (sig. (2-tailed)) of $0.014<0.05$ which means that Ho was rejected and H1 was accepted. So the average score of the mathematical representation ability of eighth grade students of SMP Negeri 2 Toari, Kolaka Regency with a methaporical thinking approach is better than conventional learning.

Based on observations of student activities in the experimental class applying the methaporical thinking approach showed students were more active in the learning process compared to the control class applying conventional learning, as indicated by the average percentage of positive student activity in the experimental class by $77.62 \%$ while in the class control is only $66.67 \%$. If the positive student activity results in the experimental class and the control class are interpreted visually in the form of a graph, then it can be described as follows. 


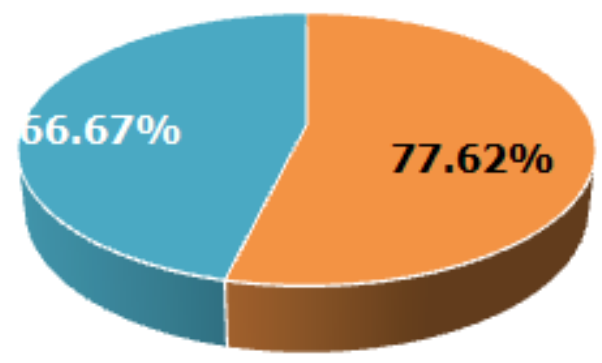

\section{- Methaporical Thinking - Konvensional}

Figure 1. Positive Activity of Experimental Class and Control Class Students

\section{CONCLUSIONS AND SUGGESTION Conclusion}

Based on the results of research and discussion, it is concluded that there is an influence from the application of the methaporical thinking approach to the mathematical representation ability of eighth grade students of SMP Negeri 2 Toari, Kolaka Regency. Students are more active in the learning process applying the methaporical thinking approach than conventional learning.

\section{Suggestion}

Suggestions that can be given to subject teachers, namely the methaporical thinking approach can be used as an alternative in learning mathematics to improve students' mathematical representation, especially in the material of straight-line equations. Other researchers can develop this research by reducing some weaknesses that might exist.

\section{REFERENCES}

Danim, Sudarwan. (2003). Riset Keperawatan Sejarah dan Metodologi. Jakarta: EGC

De Porter, Bobby. (2000). Quantum Teaching and Learning. Bandung: Kaifa

Firdaus, A.M. (2019). Application of Cooperative Learning Model Type Think Pair Share (TPS) on Mathematical Communication Ability. Jurnal Daya Matematis, 7(1), 59 - 68.

Meltzer, D.E. (2002). The Relationship between Mathematics Preparation and Conseptual Learning Gains in Physics: Posisible Hidden Variable in Diagnostic Pretest Scores. American Journal of Physics. 70(7), 1259 1268 .

NCTM. (2000). Principles and Standards for School Mathematics. Reston, VA: NCTM.

Sabirin, Muhamad. (2014). Representasi dalam Pembelajaran Matematika. Jurnal Pendidikan Matematika (JPM) IAIN Antasari, 1(2), 33 - 44

Saputri, I., Susanti, E dan Aisyah, N. (2017). Kemapuan Penalaran Matematis Siswa Menggunakan Pendekatan Methaporical Thinking pada Materi 
Perbandingan Kelas VIII di SMPN 1 Indralaya Utara. Jurnal Elemen, 3(1), $15-24$

Sugiyono. (2015). Metode Penelitian Pendidikan. Bandung: Alfabeta

Sundayana, R. (2014). Media dan Alat Peraga dalam Pembelajaran Matematika. Bandung: Alfabeta.

Suryana, Andri. (2012). Kemampuan Berpikir Tingkat Lanjut (Advanced Mathematical Thinking) dalam Mata Kuliah Statistika Matematika I. Makalah disajikan dalam Seminar Nasional Matematika dan Pendidikan Matematika 10 November 2012. Yogyakarta: Jurusan Pendidikan Matematika FPMIPA UNY 